\title{
Comparative Evaluation of Primary Stability between Different Diameters Multi-Scale Roughness Dental Implant by Solid Rigid Polyurethane Simulation
}

\author{
Margherita Tumedei ${ }^{1, *(D)}$, Morena Petrini ${ }^{1}\left(\mathbb{D}\right.$, Alessandro Cipollina ${ }^{2}(0)$, Mariastella Di Carmine ${ }^{3}$, \\ Adriano Piattelli ${ }^{4,5}$, Antonio Cucurullo ${ }^{6}$ and Giovanna Iezzi ${ }^{1}$ \\ 1 Department of Medical, Oral and Biotechnological Sciences, University “G. D'Annunzio” of Chieti-Pescara, \\ Via dei Vestini 31, 66100 Chieti (CH), Italy; petrini.morena@gmail.com (M.P.); gio.iezzi@unich.it (G.I.) \\ 2 Private Practice, Via Piacenza, 7, 92019 Sciacca (AG), Italy; alexandros1960@libero.it \\ 3 Private Practice, Via Della Fornace n 10, 65014 Loreto Aprutino (PE), Italy; mariastelladc@libero.it \\ 4 Biomaterials Engineering, Catholic University of San Antonio de Murcia (UCAM), Av. de los Jerónimos, 135, \\ 30107 Murcia, Spain; apiattelli@unich.it \\ 5 Villaserena Foundation for Research, Via Leonardo Petruzzi 42, 65013 Città Sant'Angelo (PE), Italy \\ 6 Private Practice Viale Regina Margherita, 92024 Canicattì (AG), Italy; studiocucurullo@gmail.com \\ * Correspondence: margytumedei@yahoo.it
}

Received: 4 February 2021; Accepted: 8 March 2021; Published: 12 March 2021

\begin{abstract}
Background: Implant primary stability is determined by screw characteristics and surgical procedure. The aim of the present study was to evaluate, on a polyurethane model, the insertion torque (IT), removal torque (RT), and resonance frequency analysis (RFA) of multi-scale roughness dental implants of different diameters. Methods: Two implant sizes were tested on two polyurethane blocks (20 pounds per cubic foot (PCF) and $30 \mathrm{PCF}$ ): 3.0 diameter and $13 \mathrm{~mm}$ length and 5.0 diameter and $13 \mathrm{~mm}$ length. The IT, RT, and RFA were assessed. Results: A significant difference of IT and RT was present in favor of wider implants at both polyurethane densities. No statistical difference was present between the 5.0 diameter and 3.0 diameter implants at both polyurethane densities. A statistically increased RFA was reported for 5.0 implant 30 PCF polyurethane blocks. Conclusions: Multi-scale roughness dental implants of both diameters showed high insertion torque and primary stability on polyurethane blocks, which is valuable for implant loading protocols.
\end{abstract}

Keywords: titanium surface; roughness; dental implant; solid rigid polyurethane blocks

\section{Introduction}

Primary stability is the main clinical condition for the early and long-term success of dental implant osteointegration $[1,2]$. This clinical condition determines the induction of the healing of the peri-implant tissues and permits the creation of an ankylotic relationship at the level of the bone-to implant interface, new bone formation, and remodeling [1,3].

Dental implant primary stability is defined as the mechanical friction determined by the surface contact of a clinically stable screw with the osteotomy wall during its positioning [4-7].

The presence of micromovements of over than 150 microns has been reported as a condition favorable for soft tissue interposition between the bone and implant surface inducing fibrous integration [8-13]. Bone tissue is a dynamic, highly responsive connective tissue to functional loading [3]. In the literature, it has been reported that stress and strain on stable dental implants are able to induce cortical bone modification, bone-implant contact, and density increase around the screw interface [14,15]. Several different techniques have been described for implant site preparation such as drilling protocols [16-20], osseodensification technique [21-23], ultrasonic piezoelectric device [17,24,25], 
manual osteocondensation [26], and conventional and under-preparation osteotomy [27,28]. Primary stability is also determined by the macro-geometry and thread shape of the implant [29]. Comparative studies reported, in a polyurethane block simulation, that a cylindrical implant design showed increased insertion torque (IT) and implant stability quotient (ISQ) compared to conical implants [30]. The insertion torque and removal strength are clinically determined by the micro-mechanical interaction between the dental implant and the surrounding bone wall [31]. The minimum insertion torque necessary to achieve implant osseointegration is undefined, while a positioning torque $\geq 30 \mathrm{Ncm}$ is clinically required for immediate loading protocol into healed bone ridges and post-extraction alveolar sockets [27]. The implant stability quotient (ISQ) is a reproducible, repeatable, and highly predictive measurement for dental implant stability [32]. This procedure has been proposed to evaluate the stability and clinical prognosis of teeth and dental implants in the oral cavity as a cost-effective and non-operator-dependent diagnostic technique [32].

The solid rigid polyurethane bone block has been proposed as a valuable material for orthopedics and maxillofacial medical devices [5,11,33]. The material is available in different densities and microstructures able to simulate the mechanical and physical properties of human bone and its cortical and cancellous components [34]. In the literature, many different materials have been proposed to evaluate dental implants' primary stability such as bovine or pig ribs, rabbit tibiae, sheep mandible, and cadaveric human bone [35-38]. Polyurethane blocks present a uniform density, elastic and strength characteristics, and are unaffected by desiccation [30,39].

The aim of the present investigation was to compare the primary stability between two different diameters' multi-scale roughness dental implants positioned into solid rigid polyurethane blocks of different densities.

\section{Materials and Methods}

\subsection{Polyurethane Foam Blocks}

Polyurethane solid rigid blocks represent a validated bone simulator to test the response of dental implants and medical devices in a standardized environment (ASTM F-1839-08) [11,30,39]. Polyurethane blocks present a uniform density, elastic and strength characteristics, and are unaffected by desiccation. Polyurethane presents similar properties to human bone and it requires no special handling or preservation protocol. This synthetic material presented consistent mechanical characteristics. For the present investigation, two different densities of 20-30 pounds per cubic foot (PCF) (D2-D1) of polyurethane solid rigid block (Sawbones, Vashon Island, Washington USA) with a size of $120 \times 170 \times 30 \mathrm{~mm}$ were tested.

\subsection{Implant Characteristics}

Internal hexagon cylindrical implants (IC, Resista, Omegna VB, Italy) were evaluated in the present investigation (Figures 1 and 2).

The differential multi-scale surface treatments were provided in the coronal, median, and apical portions of the device to increase the osteogenic response of the peri-implant tissues.

The cervical portion was characterized by a smooth machined surface to oppose bacteria adhesion and proliferation. The micro-thread area was provided by a nano-rough surface with $\mathrm{Ra}<1 \mu$. The presence of a textured surface is able to increase the absorption of proteins and the stabilization of blood clots, platelets, and fibrin adhesion in the healing phase, promoting implant osteointegration. 


\section{IC IMPLANTS}

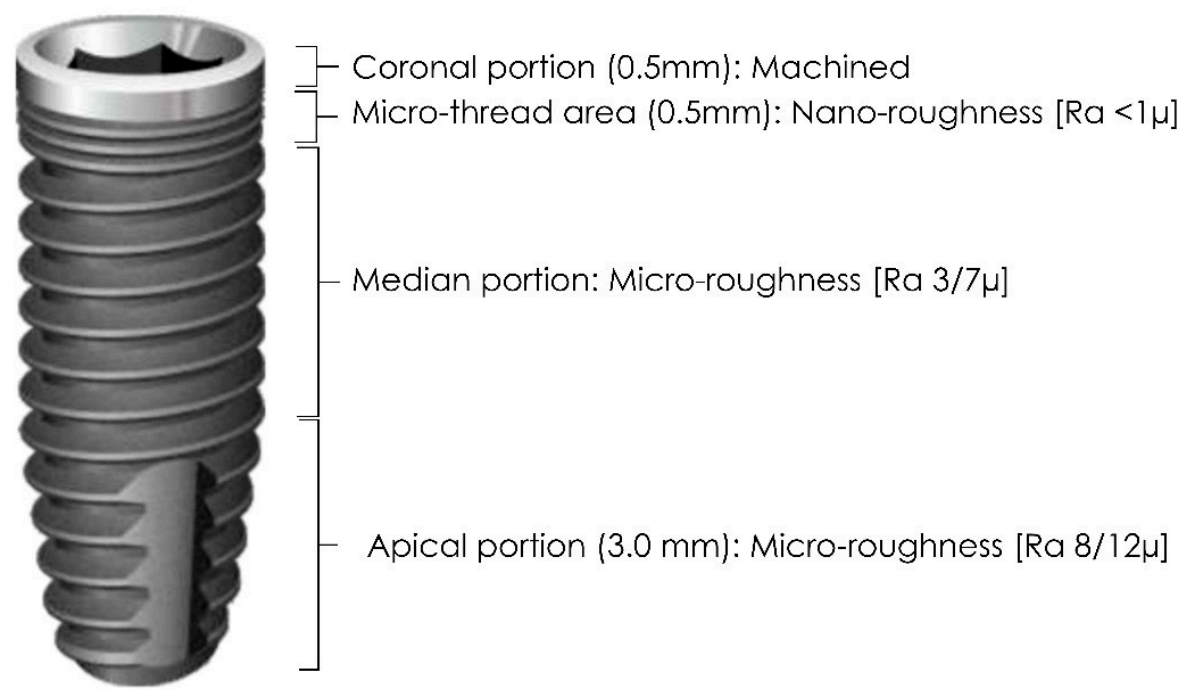

Figure 1. Main characteristics of the dental implants evaluated in the present investigation.

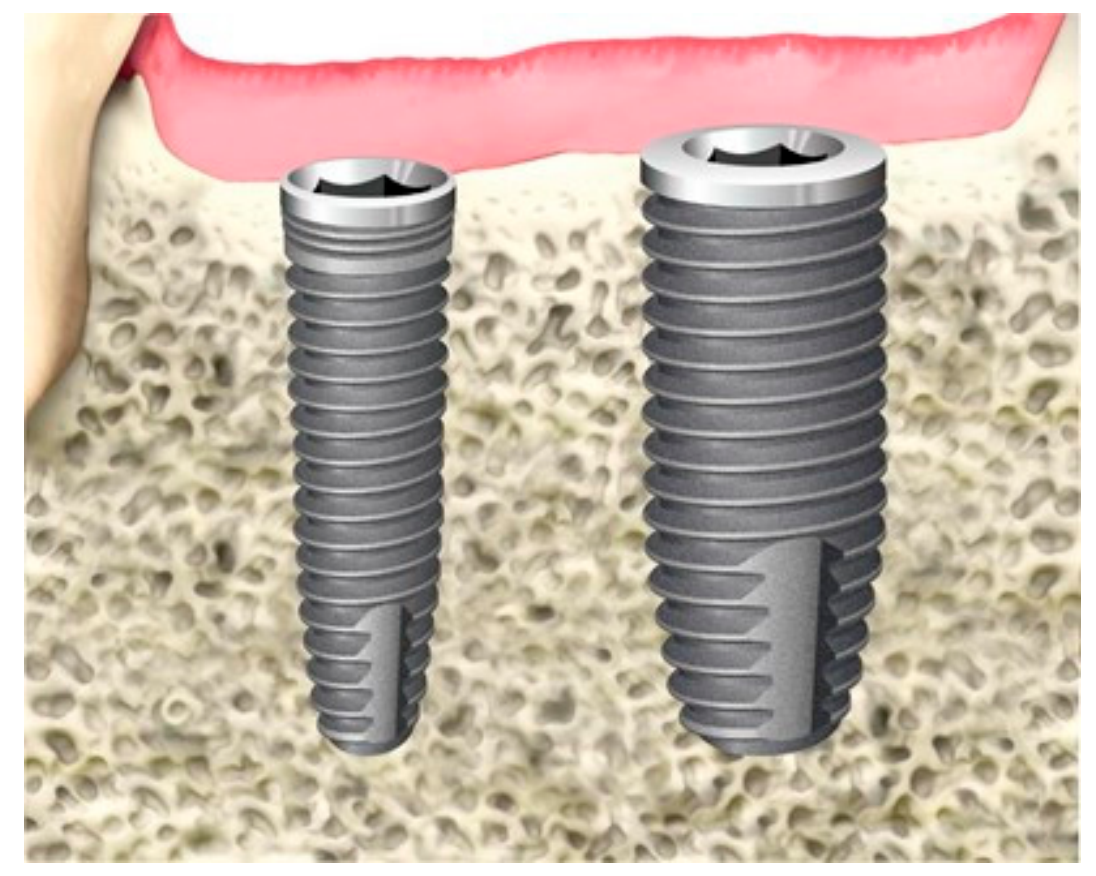

Figure 2. Optimal positioning into the bone tissue of the dental implant tested in the present investigation.

The median part of the implant screw was characterized by a dual acid-etched (DAE) micro-rough surface (mean Ra: 3/7 $\mu$ ) and the apical portion by a slow dual acid-etched (DAE) micro-rough surface (mean Ra: $8 / 12 \mu$ ).

\subsection{Drilling Protocol and Insertion (IT) and Removal Torque (RT) Assessment}

A total of 20 dental implants were positioned in the present polyurethane research. Two different solid rigid polyurethane densities were tested (SawBones H, Pacific Research Laboratories Inc, Vashon, WA, USA) (Figure 2). The polyurethane block was characterized by a closed cell range from $96.0 \%$ to $99.9 \%$. The 20-pound per cubic foot $\left(\mathrm{lb} / \mathrm{ft}^{3}\right)(\mathrm{PCF})$ polyurethane density, equal to $0.32 \mathrm{~g} / \mathrm{cm}^{3}$, presented 
similar rigidity and consistency to D2, and $30 \mathrm{PCF}$, equal to $0.48 \mathrm{~g} / \mathrm{cm}^{3}$, simulated the rigidity and consistence of D1 bone (Figure 3).

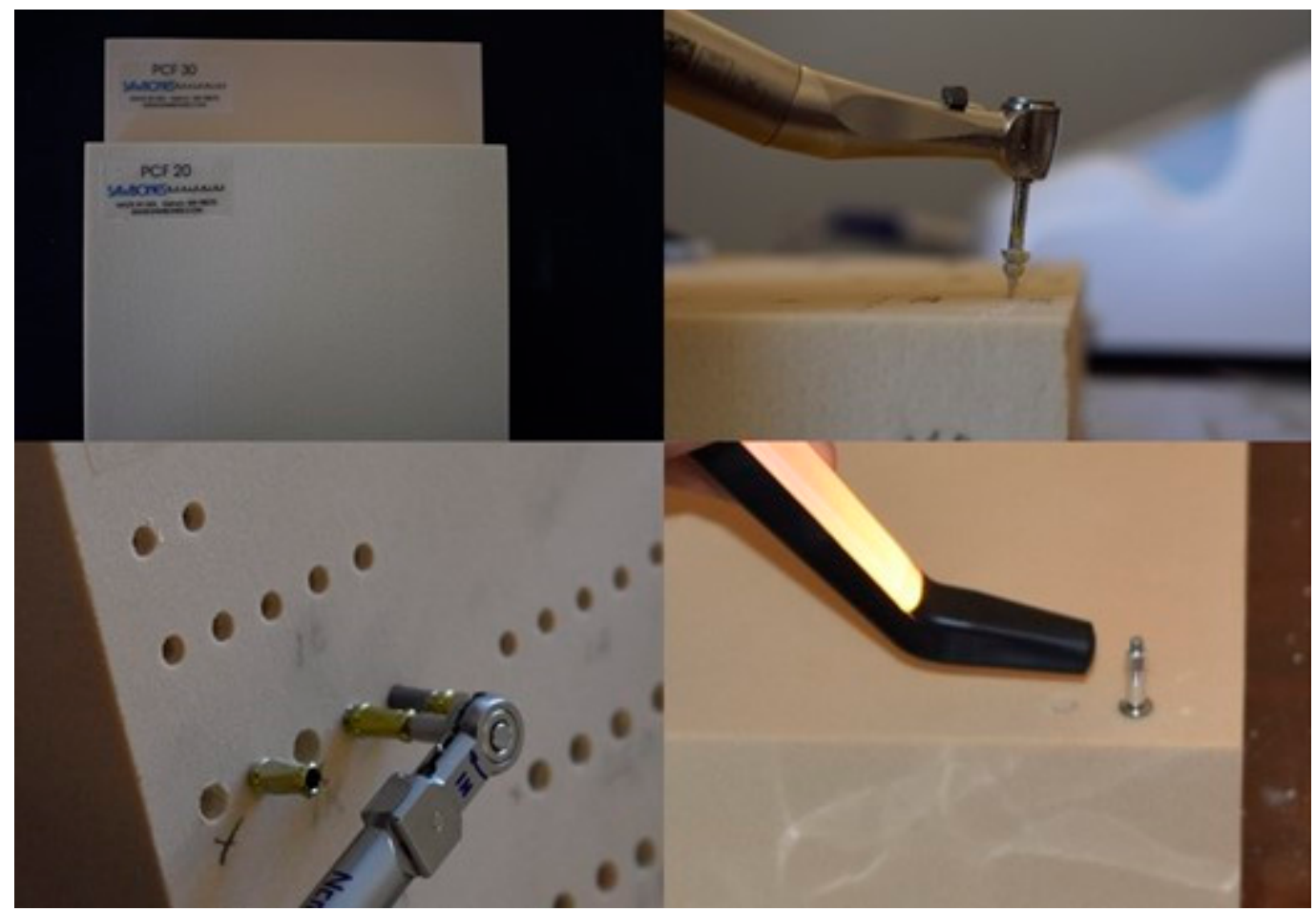

Figure 3. Details of the procedural phase of the experimental protocols.

Polyurethane solid rigid blocks (Sawbones, Vashon Island, Washington DC, USA) with two different densities of 20-30 PCF (D2-D1) were prepared for 3.0 diameter IC implant according to the following drilling protocol: lance drill, 2.0 diameter drill, 2.6 diameter drill, 2.8 diameter drill.

The implant site preparation for the 5.0 diameter IC implant was according to the following drilling protocol: lance drill, 2.0 diameter drill, 2.6 diameter drill, 2.8 diameter drill, 3.2 diameter drill, 3.8 diameter drill, 4.5 diameter drill. The surgical hand-piece was set with a speed of $800 \mathrm{rpm}$ and a torque of $30 \mathrm{Ncm}$ for implant site preparation. After the implant site preparation according to the manufacturer's protocol, the insertion torque and removal torque were recorded by dynamometric analysis during the screw positioning. Torque measurement was assessed with a software package (ImpDat Plus, East Lansing, MI, USA).

\subsection{Resonance Frequency Analysis (RFA)}

RFA (Osstell, Columbia MD USA) is an electromechanical assessment that is performed by an electronic device that measures the micromovement of an implant for a total of 16 times.

The RFA device is able to self-eliminate the non-compliant pulse offering a reliable and reproducible measurement of the implant micro-mobility.

The measurements are classified according to the implant stability quotient score (ISQ), ranging between 1 and 100:

- Good stability: >70 implant stability quotient (ISQ);

- Medium stability: 60-69 implant stability quotient (ISQ);

- Low stability: $<60$ implant stability quotient (ISQ). 


\subsection{Statistical Analysis}

The normal distribution of the study data was evaluated by the Kolmogorov-Smirnov test. A one-way ANOVA followed by the Tukey post-hoc test was performed to evaluate the statistical significance of the study variables. The study data were analyzed using the statistical software package GraphPad 8.0 (Prism, San Diego, CA, USA). The statistical significance was set at $p<0.05$.

\section{Results}

The mean IT assessment for both groups is presented in Figure 4 and Table 1. The 3.0 IC implant showed a mean IT in $20 \mathrm{PCF}$ and $30 \mathrm{PCF}$ cases of $25.80 \pm 0.8367 \mathrm{Ncm}$ and $49.40 \pm 2.702 \mathrm{Ncm}$, respectively $(p<0.05)$. A statistically significant higher IT was reported for the 5.0 IC implant at 20 PCF and 30 PCF with a mean of $51.60 \pm 1.049$ and $90.00 \pm 0.3012 \mathrm{Ncm}$, respectively $(p<0.05)$.

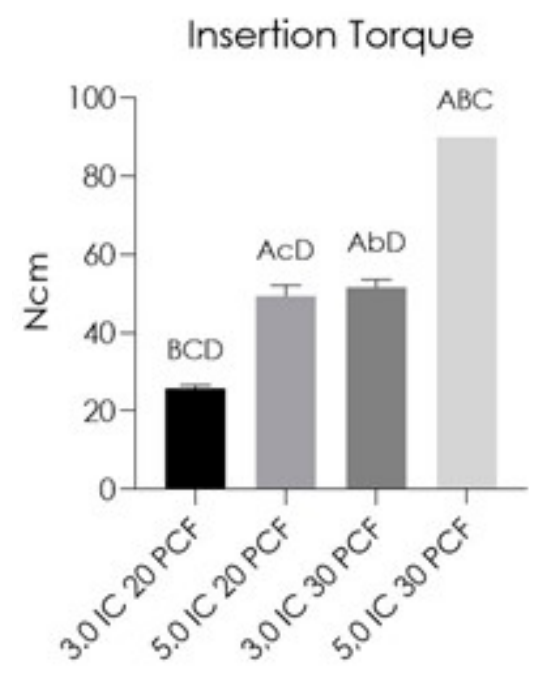

Figure 4. Insertion torque values of the 3.0 IC 20 PCF (A), 5.0 IC 20 PCF (B), 3.0 IC 30 PCF (C) and 5.0 IC 30 PCF (D) dental implants. The intergroup statistical significance comparison results are represented by capital letters $(p<0.05)$ and lowercase letters $(p>0.05)$.

Table 1. Insertion torque values of the 3.0 IC and 5.0 IC dental implants.

\begin{tabular}{ccccc}
\hline INSERTION TORQUE & 3.0 IC 20 PCF & 5.0 IC 20 PCF & 3.0 IC 30 PCF & 5.0 IC 30 PCF \\
\hline Minimum & 25.00 & 45.00 & 50.00 & 90.00 \\
25\% Percentile & 25.00 & 47.00 & 50.50 & 90.00 \\
Median & 26.00 & 50.00 & 51.00 & 90.00 \\
75\% Percentile & 26.50 & 51.50 & 53.00 & 90.00 \\
Maximum & 27.00 & 52.00 & 55.00 & 90.00 \\
Range & 2.000 & 7.000 & 5.000 & 0.000 \\
Mean & 25.80 & 49.40 & 51.60 & 90.00 \\
Std. Deviation & \pm 0.8367 & \pm 2.702 & \pm 1.949 & \pm 0.3012 \\
Std. Error of Mean & 0.3742 & 1.208 & 0.8718 & 0.000 \\
Lower 95\% CI of mean & 24.76 & 46.05 & 49.18 & 90.00 \\
Upper 95\% CI of mean & 26.84 & 52.75 & 54.02 & 90.00 \\
\hline
\end{tabular}

The mean RT measurements are presented in Figure 5 and Table 2, where the 5.0 IC implant at 20 PCF and 30 PCF showed a statistically significant higher mean RT of $51.60 \pm 1.049$ and $79.00 \pm 11.40 \mathrm{Ncm}$, respectively $(p<0.05)$. The 3.0 IC implant showed an average RT at 20 PCF and $30 \mathrm{PCF}$ of $24.80 \pm 1.304$ and $46.00 \pm 2.345 \mathrm{Ncm}$, respectively $(p<0.05)$. 


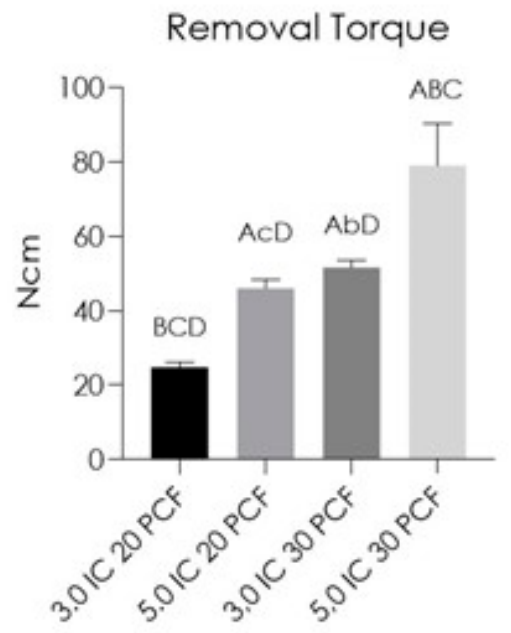

Figure 5. Removal torque values of the 3.0 IC 20 PCF (A), 5.0 IC 20 PCF (B), 3.0 IC 30 PCF (C) and 5.0 IC 30 PCF (D) dental implants. The intergroup statistical significance comparison results are represented by capital letters $(p<0.05)$ and lowercase letters $(p>0.05)$.

Table 2. Removal torque values of the 3.0 IC and 5.0 IC dental implants.

\begin{tabular}{ccccc}
\hline REMOVAL TORQUE & 3.0 IC 20 PCF & 5.0 IC 20 PCF & 3.0 IC 30 PCF & 5.0 IC 30 PCF \\
\hline Minimum & 23.00 & 43.00 & 50.00 & 60.00 \\
25\% Percentile & 23.50 & 43.50 & 50.50 & 70.00 \\
Median & 25.00 & 47.00 & 51.00 & 80.00 \\
75\% Percentile & 26.00 & 48.00 & 53.00 & 87.50 \\
Maximum & 26.00 & 48.00 & 55.00 & 90.00 \\
Range & 3.000 & 5.000 & 5.000 & 30.00 \\
\hline Mean & 24.80 & 46.00 & 51.60 & 79.00 \\
Std. Deviation & \pm 1.304 & \pm 2.345 & \pm 1.949 & \pm 11.40 \\
\hline Std. Error of Mean & 0.5831 & 1.049 & 0.8718 & 5.099 \\
Lower 95\% CI of mean & 23.18 & 43.09 & 49.18 & 64.84 \\
Upper 95\% CI of mean & 26.42 & 48.91 & 54.02 & 93.16 \\
\hline
\end{tabular}

The mean RFA measurements for both groups are presented in Figure 6 and Table 3.

\section{RFA}

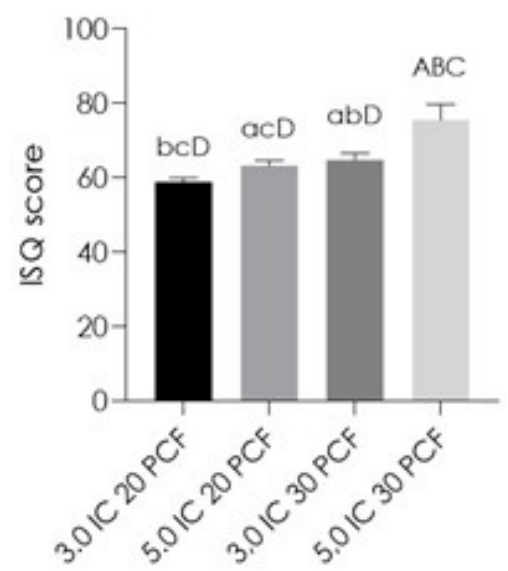

Figure 6. Resonance frequency analysis (RFA) values of the 3.0 IC 20 PCF (A), 5.0 IC 20 PCF (B), 3.0 IC 30 PCF (C) and 5.0 IC 30 PCF (D) dental implants. The intergroup statistical significance comparison results are represented by capital letters $(p<0.05)$ and lowercase letters $(p>0.05)$. 
Table 3. RFA values of the 3.0 IC and 5.0 IC dental implants.

\begin{tabular}{ccccc}
\hline RFA & 3.0 IC 20 PCF & 5.0 IC 20 PCF & 3.0 IC 30 PCF & 5.0 IC 30 PCF \\
\hline Minimum & 58.00 & 61.00 & 62.50 & 68.00 \\
25\% Percentile & 58.00 & 62.25 & 63.00 & 72.25 \\
Median & 58.50 & 63.50 & 65.50 & 77.00 \\
75\% Percentile & 60.00 & 64.25 & 66.25 & 78.00 \\
Maximum & 60.50 & 64.50 & 67.00 & 78.50 \\
Range & 2.500 & 3.500 & 4.500 & 10.50 \\
Mean & 58.90 & 63.30 & 64.80 & 75.50 \\
Std. Deviation & \pm 1.084 & \pm 1.351 & \pm 1.789 & \pm 4.257 \\
Std. Error of Mean & 0.4848 & 0.6042 & 0.8000 & 1.904 \\
Lower 95\% CI of mean & 57.55 & 61.62 & 62.58 & 70.21 \\
Upper 95\% CI of mean & 60.25 & 64.98 & 67.02 & 80.79 \\
\hline
\end{tabular}

The 3.0 IC implant showed a mean implant stability quotient (ISQ) value at 20 PCF and 30 PCF of $58.90 \pm 1.084$ and $63.30 \pm 1.351$, respectively $(p>0.05)$. The 5.0 IC implant at 20 PCF showed a mean value of $64.80 \pm 1.789(p<0.05)$. A statistically significant higher RFA measurement was reported for the 5.0 IC implant at 30 PCF with an average ISQ value of $75.50 \pm 4.257$. The aim of the present investigation was to evaluate the primary stability of cylindrical multi-scale roughness dental implants of two different diameters.

\section{Discussion}

The rationale of the present investigation was to evaluate the effect of different sizes of implant diameter on primary stability through a standardized simulation on an artificial polyurethane model. The implant choice was made in accordance with the recent and most diffused macro-geometry and internal prosthetic platform for endosseous implants in order to preserve the experimental repeatability and reduce the study variables [40].

The choice of the appropriate implant diameter is clinically determined by prosthetic factors, aesthetics, the residual thickness of the bone ridge, and the distance between adjacent elements [41]. A minimum distance of $1.4-2 \mathrm{~mm}$ should be always maintained between the marginal bone and the implant surface [42]. The implant positioning could be affected by anatomical features such as knife-edged alveolar ridges that require a regenerative approach [42,43]. Primary stability is determined by different mechanical and frictional factors such as absence of micromovements, implant design, screw size and diameter, bone quality, and surgical technique [1,15].

The adoption of an increased implant diameter of $1 \mathrm{~mm}$ is able to induce a higher surface contact area percentage with the surrounding tissues by between $30 \%$ and $200 \%$, which could actively influence the primary stability and the functional bone stress distribution [44].

In the present investigation, both dental implant diameters showed a high insertion torque value $(>25 \mathrm{Ncm}$ ). Moreover, no significant difference in terms of ISQ stability was present at both 20 PCF and 30 PCF polyurethane densities $(p>0.05)$.

Clinically, the presence of optimal primary stability also with a reduced dental implant diameter could represent a determining factor that could contribute to the rehabilitation of regions with limited prosthetic space and/or bone thickness $[45,46]$. This effectiveness could be further improved by adopting solidarized implants for an immediate or delayed protocol of functional loading [6].

Multi-scale roughness represents a surface treatment able to create differentiated roughness levels in the various parts of an implant screw. The most common implant surface treatments are machining, sandblasted surfaces, acid-etched treatment, lasered surfaces, and anodized titanium surfaces $[47,48]$. The coronal part is critical for potential early bacteria colonization of the peri-implant tissue [49]. Rodriguez and Baena et al. reported in vitro that machined titanium and nano-roughness surface are able to reduce the bacterial adhesion of Aggregatibacter actinomycetecomitans, Streptococcus mutans, and Streptococcus sanguis strains [49]. Moreover, the authors reported the lowest amount of 
bacterial contamination for the nano-roughness surface. It is well known in the literature that the micro-roughness surface rugophilia is a key factor for the induction of osteogenic actors' activity $[49,50]$. Several studies reported in animal experiments that implant micro-roughness is associated with higher bone-to-implant contact compared to machined implants [51-54]. In this way, implant surface treatment is important to create wettability and an optimal environment for early stabilization of blood clots and for supporting the integration healing of the implant $[55,56]$. Blood and proteins' adsorption seems to be related to direct bone osteogenesis from the implant surface oriented to the implant site bone wall [3]. Distance osteogenesis is associated, in the literature, to machined topography, with an osteogenesis vector oriented from the old bone to the implant surface [3].

\section{Conclusions}

In conclusion, both of the diameters tested for multi-scale roughness dental implants positioned in synthetic bone models showed enhanced primary stability that is valuable for implant loading protocols. The larger implant diameter should be preferred in the case of bone volume availability to obtain higher primary stability.

Author Contributions: Conceptualization, A.P. and G.I.; methodology, M.T., A.P., M.P. and M.D.C.; software, A.C. (Alessandro Cipollina) and M.T.; validation, A.P., G.I. and A.C. (Antonio Cucurullo); formal analysis, A.P.; investigation, A.C. (Alessandro Cipollina), M.T., M.P. and M.D.C.; writing-original draft preparation, M.T. and A.P.; writing-review and editing, M.T. and A.P. All authors have read and agreed to the published version of the manuscript.

Funding: This research received no external funding.

Institutional Review Board Statement: Not applicable.

Informed Consent Statement: Not applicable.

Data Availability Statement: The study data are available upon request to the corresponding author.

Acknowledgments: The authors declare no acknowledgments for the present research.

Conflicts of Interest: The authors declare no conflict of interest.

\section{References}

1. Monje, A.; Ravidà, A.; Wang, H.-L.; Helms, J.A.; Brunski, J.B. Relationship Between Primary/Mechanical and Secondary/Biological Implant Stability. Int. J. Oral Maxillofac. Implant. 2019, 34, s7-s23. [CrossRef]

2. Di Stefano, D.A.; Arosio, P.; Gastaldi, G.; Gherlone, E. The Insertion Torque-Depth Curve Integral as a Measure of Implant Primary Stability: An In Vitro Study on Polyurethane Foam Blocks. J. Prosthet. Dent. 2018, 120, 706-714. [CrossRef]

3. Davies, J.E. Understanding Peri-Implant Endosseous Healing. J. Dent. Educ. 2003, 67, 932-949. [CrossRef]

4. de Oliveira Nicolau Mantovani, A.K.; de Mattias Sartori, I.A.; Azevedo-Alanis, L.R.; Tiossi, R.; Fontão, F.N.G.K. Influence of Cortical Bone Anchorage on the Primary Stability of Dental Implants. Oral Maxillofac. Surg. 2018, 22, 297-301. [CrossRef]

5. Comuzzi, L.; Tumedei, M.; Pontes, A.E.; Piattelli, A.; Iezzi, G. Primary Stability of Dental Implants in Low-Density (10 and 20 Pcf) Polyurethane Foam Blocks: Conical vs Cylindrical Implants. Int. J. Environ. Res. Public Health 2020, 17, 2617. [CrossRef]

6. Del Giudice, R.; Piattelli, A.; Grande, N.-M.; Cataneo, E.; Crispino, A.; Petrini, M. Implant Insertion Torque Value in Immediate Loading: A Retrospective Study. Med. Oralpatol. Oral Y Cir. Bucal 2019, 24, e398-e403. [CrossRef] [PubMed]

7. Tumedei, M.; Piattelli, A.; Degidi, M.; Mangano, C.; Iezzi, G. A 30-Year (1988-2018) Retrospective Microscopical Evaluation of Dental Implants Retrieved for Different Causes: A Narrative Review. Int. J. Periodontics Restor. Dent. 2020, 40, e211-e227. [CrossRef] [PubMed]

8. Goellner, M.; Schmitt, J.; Karl, M.; Wichmann, M.; Holst, S. The Effect of Axial and Oblique Loading on the Micromovement of Dental Implants. Int. J. Oral Maxillofac. Implant. 2011, 26, 257-264. 
9. Freitas, A.C.; Bonfante, E.A.; Giro, G.; Janal, M.N.; Coelho, P.G. The Effect of Implant Design on Insertion Torque and Immediate Micromotion. Clin. Oral Implant. Res. 2012, 23, 113-118. [CrossRef] [PubMed]

10. Tumedei, M.; Piattelli, A.; Degidi, M.; Mangano, C.; Iezzi, G. A Narrative Review of the Histological and Histomorphometrical Evaluation of the Peri-Implant Bone in Loaded and Unloaded Dental Implants. A 30-Year Experience (1988-2018). Int. J. Environ. Res. Public Health 2020, 17, 2088. [CrossRef] [PubMed]

11. Comuzzi, L.; Tumedei, M.; Piattelli, A.; Iezzi, G. Short vs. Standard Length Cone Morse Connection Implants: An In Vitro Pilot Study in Low Density Polyurethane Foam. Symmetry 2019, 11, 1349. [CrossRef]

12. Fujiwara, S.; Kato, S.; Bengazi, F.; Urbizo Velez, J.; Tumedei, M.; Kotsu, M.; Botticelli, D. Healing at Implants Installed in Osteotomies Prepared Either with a Piezoelectric Device or Drills: An Experimental Study in Dogs. Oral Maxillofac. Surg. 2020, 25, 65-73. [CrossRef] [PubMed]

13. Kotsu, M.; Urbizo Velez, J.; Bengazi, F.; Tumedei, M.; Fujiwara, S.; Kato, S.; Botticelli, D. Healing at Implants Installed from $~ 70-$ to $<10-\mathrm{Ncm}$ Insertion Torques: An Experimental Study in Dogs. Oral Maxillofac. Surg. 2020, 25, 55-64. [CrossRef] [PubMed]

14. Al-Sabbagh, M.; Eldomiaty, W.; Khabbaz, Y. Can Osseointegration Be Achieved Without Primary Stability? Dent. Clin. N. Am. 2019, 63, 461-473. [CrossRef]

15. Greenstein, G.; Cavallaro, J. Implant Insertion Torque: Its Role in Achieving Primary Stability of Restorable Dental Implants. Compend. Contin. Educ. Dent. (Jamesburg NJ) 2017, 38, 88-95.

16. Palaskar, J.N.; Joshi, N.; Shah, P.M.; Gullapalli, P.; Vinay, V. Influence of Different Implant Placement Techniques to Improve Primary Implant Stability in Low-Density Bone: A Systematic Review. J. Indian Prosthodont. Soc. 2020, 20, 11-16. [CrossRef] [PubMed]

17. Scarano, A.; Carinci, F.; Lorusso, F.; Festa, F.; Bevilacqua, L.; Santos de Oliveira, P.; Maglione, M. Ultrasonic vs Drill Implant Site Preparation: Post-Operative Pain Measurement Through VAS, Swelling and Crestal Bone Remodeling: A Randomized Clinical Study. Materials (Basel Switz.) 2018, 11, 2516. [CrossRef]

18. Scarano, A.; Lorusso, F.; Noumbissi, S. Infrared Thermographic Evaluation of Temperature Modifications Induced during Implant Site Preparation with Steel vs. Zirconia Implant Drill. J. Clin. Med. 2020, 9, 148. [CrossRef]

19. Scarano, A.; Crincoli, V.; Di Benedetto, A.; Cozzolino, V.; Lorusso, F.; Podaliri Vulpiani, M.; Grano, M.; Kalemaj, Z.; Mori, G.; Grassi, F.R. Bone Regeneration Induced by Bone Porcine Block with Bone Marrow Stromal Stem Cells in a Minipig Model of Mandibular "Critical Size" Defect. Stem Cells Int. 2017, 2017, 9082869. [CrossRef]

20. Scarano, A.; Petrini, M.; Mastrangelo, F.; Noumbissi, S.; Lorusso, F. The Effects of Liquid Disinfection and Heat Sterilization Processes on Implant Drill Roughness: Energy Dispersion X-Ray Microanalysis and Infrared Thermography. J. Clin. Med. 2020, 9, 1019. [CrossRef]

21. Pai, U.Y.; Rodrigues, S.J.; Talreja, K.S.; Mundathaje, M. Osseodensification-A Novel Approach in Implant Dentistry. J. Indian Prosthodont. Soc. 2018, 18, 196-200. [CrossRef] [PubMed]

22. Fanali, S.; Tumedei, M.; Pignatelli, P.; Inchingolo, F.; Pennacchietti, P.; Pace, G.; Piattelli, A. Implant Primary Stability with an Osteocondensation Drilling Protocol in Different Density Polyurethane Blocks. Comput. Methods Biomech. Biomed. Eng. 2020, 25, 1-7. [CrossRef]

23. Gehrke, S.A.; Mazón, P.; Del Fabbro, M.; Tumedei, M.; Aramburú Júnior, J.; Pérez-Díaz, L.; De Aza, P.N. Histological and Histomorphometric Analyses of Two Bovine Bone Blocks Implanted in Rabbit Calvaria. Symmetry 2019, 11, 641. [CrossRef]

24. Vayron, R.; Mathieu, V.; Michel, A.; Haïat, G. Assessment of in Vitro Dental Implant Primary Stability Using an Ultrasonic Method. Ultrasound Med. Biol. 2014, 40, 2885-2894. [CrossRef]

25. Zizzari, V.L.; Berardi, D.; Congedi, F.; Tumedei, M.; Cataldi, A.; Perfetti, G. Morphological Aspect and INOS and Bax Expression Modification in Bone Tissue Around Dental Implants Positioned Using Piezoelectric Bone Surgery Versus Conventional Drill Technique. J. Craniofacial Surg. 2015, 26, 741-744. [CrossRef] [PubMed]

26. Al-Almaie, S. Osteotome-Assisted Lateral Bone Expansion and Condensation with Immediate Dental Implants Placements. 2017. Available online: https://academicreads.com/wp-content/uploads/2017/10/DI-1704-1_C.pdf (accessed on 12 December 2020).

27. Degidi, M.; Daprile, G.; Piattelli, A. Influence of Underpreparation on Primary Stability of Implants Inserted in Poor Quality Bone Sites: An in Vitro Study. J. Oral Maxillofac. Surg. Off. J. Am. Assoc. Oral Maxillofac. Surg. 2015, 73, 1084-1088. [CrossRef] 
28. Anitua, E.; Murias-Freijo, A.; Alkhraisat, M.H. Implant Site Under-Preparation to Compensate the Remodeling of an Autologous Bone Block Graft. J. Craniofacial Surg. 2015, 26, e374-e377. [CrossRef]

29. Falisi, G.; Severino, M.; Rastelli, C.; Bernardi, S.; Caruso, S.; Galli, M.; Lamazza, L.; Di Paolo, C. The Effects of Surgical Preparation Techniques and Implant Macro-Geometry on Primary Stability: An in Vitro Study. Med. Oralpatol. Oral Y Cir. Bucal 2017, 22, e201-e206. [CrossRef]

30. Comuzzi, L.; Iezzi, G.; Piattelli, A.; Tumedei, M. An In Vitro Evaluation, on Polyurethane Foam Sheets, of the Insertion Torque (IT) Values, Pull-Out Torque Values, and Resonance Frequency Analysis (RFA) of NanoShort Dental Implants. Polymers 2019, 11, 1020. [CrossRef] [PubMed]

31. Staedt, H.; Palarie, V.; Staedt, A.; Wolf, J.M.; Lehmann, K.M.; Ottl, P.; Kämmerer, P.W. Primary Stability of Cylindrical and Conical Dental Implants in Relation to Insertion Torque-A Comparative Ex Vivo Evaluation. Implant Dent. 2017, 26, 250-255. [CrossRef]

32. Kastala, V.H.; Ramoji Rao, M.V. Comparative Evaluation of Implant Stability in Two Different Implant Systems at Baseline and 3-4 Months Intervals Using RFA Device (OSSTELL ISQ). Indian J. Dent. Res. Off. Publ. Indian Soc. Dent. Res. 2019, 30, 678-686. [CrossRef]

33. Gehrke, S.A.; Tumedei, M.; Aramburú Júnior, J.; Treichel, T.L.E.; Kolerman, R.; Lepore, S.; Piattelli, A.; Iezzi, G. Histological and Histomorphometrical Evaluation of a New Implant Macrogeometry. A Sheep Study. Int. J. Environ. Res. Public Health 2020, 17, 3477. [CrossRef]

34. Miyashiro, M.; Suedam, V.; Moretti Neto, R.T.; Ferreira, P.M.; Rubo, J.H. Validation of an Experimental Polyurethane Model for Biomechanical Studies on Implant Supported Prosthesis-Tension Tests. J. Appl. Oral Sci. Rev. Fob 2011, 19, 244-248. [CrossRef]

35. Scarano, A.; Iezzi, G.; Perrotti, V.; Tetè, S.; Staiti, G.; Mortellaro, C.; Cappucci, C. Ultrasonic versus Drills Implant Site Preparation: A Histologic Analysis in Bovine Ribs. J. Craniofacial Surg. 2014, 25, 814-817. [CrossRef] [PubMed]

36. Trisi, P.; Berardini, M.; Falco, A.; Podaliri Vulpiani, M. New Osseodensification Implant Site Preparation Method to Increase Bone Density in Low-Density Bone: In Vivo Evaluation in Sheep. Implant Dent. 2016, 25, 24-31. [CrossRef]

37. Kalemaj, Z.; Scarano, A.; Valbonetti, L.; Rapone, B.; Grassi, F.R. Bone Response to Four Dental Implants with Different Surface Topographies: A Histologic and Histometric Study in Minipigs. Int. J. Periodontics Restor. Dent. 2016, 36, 745-754. [CrossRef] [PubMed]

38. Möhlhenrich, S.C.; Heussen, N.; Winterhalder, P.; Prescher, A.; Hölzle, F.; Modabber, A.; Wolf, M.; Kniha, K. Predicting Primary Stability of Orthodontic Mini-Implants, According to Position, Screw-Size, and Bone Quality, in the Maxilla of Aged Patients: A Cadaveric Study. Eur. J. Oral Sci. 2019, 127, 462-471. [CrossRef] [PubMed]

39. ASTM. ASTM F 67-95: Standard Specification for Unalloyed Titanium for Surgical Implant Applications. In Annual Book of ASTM Standards; American Society for Testing and Materials: Philadelphia, PA, USA, 1995.

40. Dental Implants Market Report Size, Share, Growth \& Report [2027]. Available online: https: //www.fortunebusinessinsights.com/industry-reports/dental-implants-market-100443 (accessed on 20 February 2021).

41. Hsu, J.-T.; Shen, Y.-W.; Kuo, C.-W.; Wang, R.-T.; Fuh, L.-J.; Huang, H.-L. Impacts of 3D Bone-to- Implant Contact and Implant Diameter on Primary Stability of Dental Implant. J. Formos. Med Assoc./Taiwan Yi Zhi 2017, 116, 582-590. [CrossRef] [PubMed]

42. Tarnow, D.P.; Cho, S.C.; Wallace, S.S. The Effect of Inter-Implant Distance on the Height of Inter-Implant Bone Crest. J. Periodontol. 2000, 71, 546-549. [CrossRef] [PubMed]

43. Tarnow, D.; Elian, N.; Fletcher, P.; Froum, S.; Magner, A.; Cho, S.-C.; Salama, M.; Salama, H.; Garber, D.A. Vertical Distance from the Crest of Bone to the Height of the Interproximal Papilla between Adjacent Implants. J. Periodontol. 2003, 74, 1785-1788. [CrossRef] [PubMed]

44. Misch, C.E.; Strong, I.T.; Bidez, M.W. Implant Design. In Contemporary Implant Dentistry; Mosby: St. Louis, MI, USA, 2007; p. 200.

45. Pan, C.-Y.; Liu, P.-H.; Tseng, Y.-C.; Chou, S.-T.; Wu, C.-Y.; Chang, H.-P. Effects of Cortical Bone Thickness and Trabecular Bone Density on Primary Stability of Orthodontic Mini-Implants. J. Dent. Sci. 2019, 14, 383-388. [CrossRef] 
46. Divac, M.; Stawarczyk, B.; Sahrmann, P.; Attin, T.; Schmidlin, P.R. Influence of Residual Bone Thickness on Primary Stability of Hybrid Self-Tapping and Cylindric Non-Self-Tapping Implants in Vitro. Int. J. Oral Maxillofac. Implant. 2013, 28, 84-88. [CrossRef]

47. Jemat, A.; Ghazali, M.J.; Razali, M.; Otsuka, Y. Surface Modifications and Their Effects on Titanium Dental Implants. BioMed Res. Int. 2015, 2015, 791725. [CrossRef] [PubMed]

48. Scarano, A.; Crocetta, E.; Quaranta, A.; Lorusso, F. Influence of the Thermal Treatment to Address a Better Osseointegration of Ti6Al4V Dental Implants: Histological and Histomorphometrical Study in a Rabbit Model. BioMed Res. Int. 2018, 2018, 2349698. [CrossRef] [PubMed]

49. Rodriguez y Baena, R.; Arciola, C.R.; Selan, L.; Battaglia, R.; Imbriani, M.; Rizzo, S.; Visai, L. Evaluation of Bacterial Adhesion on Machined Titanium, Osseotite ${ }^{\circledR}$ and Nanotite ${ }^{\circledR}$ Discs. Int. J. Artif. Organs 2012, 35, 754-761. [CrossRef] [PubMed]

50. D'Ercole, S.; Cellini, L.; Pilato, S.; Di Lodovico, S.; Iezzi, G.; Piattelli, A.; Petrini, M. Material Characterization and Streptococcus Oralis Adhesion on Polyetheretherketone (PEEK) and Titanium Surfaces Used in Implantology. J. Mater. Science. Mater. Med. 2020, 31, 84. [CrossRef] [PubMed]

51. Scarano, A.; Piattelli, A.; Quaranta, A.; Lorusso, F. Bone Response to Two Dental Implants with Different Sandblasted/Acid-Etched Implant Surfaces: A Histological and Histomorphometrical Study in Rabbits. BioMed Res. Int. 2017, 2017, 8724951. [CrossRef]

52. Velasco, E.; Monsalve-Guil, L.; Jimenez, A.; Ortiz, I.; Moreno-Muñoz, J.; Nuñez-Marquez, E.; Pegueroles, M.; Pérez, R.A.; Gil, F.J. Importance of the Roughness and Residual Stresses of Dental Implants on Fatigue and Osseointegration Behavior. In Vivo Study in Rabbits. J. Oral Implantol. 2016, 42, 469-476. [CrossRef]

53. Scarano, A.; Lorusso, F.; Staiti, G.; Sinjari, B.; Tampieri, A.; Mortellaro, C. Sinus Augmentation with Biomimetic Nanostructured Matrix: Tomographic, Radiological, Histological and Histomorphometrical Results after 6 Months in Humans. Front. Physiol. 2017, 8, 565. [CrossRef]

54. Scarano, A.; Lorusso, F.; Arcangelo, M.; D'Arcangelo, C.; Celletti, R.; de Oliveira, P.S. Lateral Sinus Floor Elevation Performed with Trapezoidal and Modified Triangular Flap Designs: A Randomized Pilot Study of Post-Operative Pain Using Thermal Infrared Imaging. Int. J. Environ. Res. Public Health 2018, 15, 1277. [CrossRef]

55. Elias, C.N.; Oshida, Y.; Lima, J.H.C.; Muller, C.A. Relationship between Surface Properties (Roughness, Wettability and Morphology) of Titanium and Dental Implant Removal Torque. J. Mech. Behav. Biomed. Mater. 2008, 1, 234-242. [CrossRef] [PubMed]

56. Hotchkiss, K.M.; Reddy, G.B.; Hyzy, S.L.; Schwartz, Z.; Boyan, B.D.; Olivares-Navarrete, R. Titanium Surface Characteristics, Including Topography and Wettability, Alter Macrophage Activation. Acta Biomater. 2016, 31, 425-434. [CrossRef] [PubMed]

Publisher's Note: MDPI stays neutral with regard to jurisdictional claims in published maps and institutional affiliations.

(C) 2021 by the authors. Licensee MDPI, Basel, Switzerland. This article is an open access article distributed under the terms and conditions of the Creative Commons Attribution (CC BY) license (http://creativecommons.org/licenses/by/4.0/). 